\title{
Pertumbuhan Cacing Tanah (Lumbricus rubellus) dan Komposisi Kompos pada Media yang Diperkaya Limbah Rumah Makan dan Limbah Industri Tahu
}

\section{Earthworms (Lumbricus rubellus) Growth and Compost Compositions in Media Enriched with Food Waste and Tofu Industrial Waste}

\author{
Richard D. Anggada*, Sucahyo, dan Susanti Pudji Hastuti \\ Fakultas Biologi Universitas Kristen Satya Wacana \\ Jl. Diponegoro 52-60, Salatiga \\ *Email : richardsuwitowidjojo@gmail.com
}

Diterima 9 Juli 2019 /Disetujui 11 Agustus 2019

\begin{abstract}
ABSTRAK
Penelitian ini dilakukan untuk mengetahui komposisi media terbaik untuk pertumbuhan cacing tanah $(L$. rubellus), ditinjau dari perubahan panjang akhir, laju pertumbuhan relatif berdasarkan panjang, massa basah, dan massa kering akhir, dan mengetahui komposisi kompos yang dihasilkan dari media yang diperkaya limbah rumah makan dan limbah industri tahu. Penelitian dilakukan secara eksperimental menggunakan Rancangan Acak Lengkap (RAL) 4 variasi selama 60 hari. Masing-masing perlakuan dibuat 5x ulangan. Hasil pertumbuhan cacing pada perlakuan 25\% kotoran sapi : 25\% limbah rumah makan : 50\% limbah tahu tidak dapat diukur karena cacing 100\% mati. Perlakuan dengan 50\% kotoran sapi : $25 \%$ limbah rumah makan : 25\% limbah tahu menunjukkan hasil paling baik untuk mendukung pertumbuhan cacing tanah ditinjau dari panjang tubuh akhir, laju pertumbuhan relatif, massa basah akhir, dan massa kering akhir. Kompos yang dihasilkan dari ketiga perlakuan menunjukan Kadar $\mathrm{C}$ organik, kadar hara makro (N, P, dan $\mathrm{K}$ ), serta $\mathrm{pH}$ sudah sesuai dengan standar Peraturan Menteri Pertanian (Permentan) No. 70 tahun 2011 tentang Pupuk Organik, Pupuk Hayati dan Pembenah Tanah.
\end{abstract}

Kata kunci : laju pertumbuhan, C organik, hara makro

\section{ABSTRACT}

The purposes of this research were firstly, to determine the best media compositions for the growth of earthworms (L. Rubellus), in terms of changes in final length, relative growth rate based on length, wet mass, and final dry mass and secondly, to know the compositions of compost produced from media enriched with food waste and tofu industrial waste. The study was carried out experimentally using Completely Randomized Designs (CRD) with 4 variations during 60 days. Each treatment was replicated 5 times. The results of the growth of earthworms in the treatment of $25 \%$ cow manure : $25 \%$ of food waste : $50 \%$ of tofu industrial waste could not be measured because the earthworms are 100\% dead. Treatment with 50\% cow manure : $25 \%$ of food waste : $25 \%$ of tofu industrial waste shows the best results to support earthworms growth in terms of final body length, relative growth rate, final wet mass, and final dry mass. Compost produced from the three treatments showed organic $\mathrm{C}$ levels, macro nutrient levels $(\mathrm{N}, \mathrm{P}$, and $\mathrm{K})$, and $\mathrm{pH}$ were in accordance with the standards of the Minister of Agriculture Regulation No. 70 of 2011 concerning Organic Fertilizers, Biofertilizers and Soil Improvement.

Keywords : growth rate, $C$ organic, macro nutrient

\section{PENDAHULUAN}

Cacing tanah (Lumbricus rubellus) merupakan hewan dari Filum Annelida, Kelas Clitellata, Ordo Haplotaxida, Keluarga Lunbricidae, Marga Lumbricus yang hidup di habitat tanah gembur dan lembab. Spesies ini sering digunakan untuk pakan ternak karena kandungan protein $65 \%$ lebih tinggi dibanding dari protein daging mamalia dan 50\% lebih banyak dibanding pada ikan, sebagai obat sakit tifus, dan dibudidayakan untuk 
pengolahan limbah sebagai pupuk (Palungkun, 1999).

Daya dukung lingkungan seperti luas wilayah dan ketersediaan makanan akan mempengaruhi perkembangbiakan $L$. rubellus untuk dibudidayakan, pada lingkungan yang tepat dapat dihasilkan 1.500 ekor L. rubellus dalam satu tahun dari sepasang L. rubellus dewasa. L. rubellus akan membatasi laju perkembangbiakan apabila kepadatan populasi meningkat dan ketersediaan makanan semakin terbatas (Rukmana, 1999). Budidaya L. rubellus tergolong mudah karena hewan ini termasuk hewan hermaphrodite, artinya hewan ini bisa melakukan perkawinan dengan individu lain tanpa dibatasi jenis kelamin. $L$. rubellus akan aktif untuk melakukan perkawinan pada kondisi hangat dan lembab (Hermawan, 2014).

Cacing tanah dewasa (usia 10 minggu) dapat kawin setiap 10 hari sekali dan menghasilkan satu atau dua kokon dengan masing-masing kokon menampung sekitar 10 telur. Penetasan telur akan dipengaruhi oleh suhu lingkungan, berkisar tiga minggu hingga tiga bulan. Optimum pada suhu 60 ${ }^{0} \mathrm{~F}$ hingga $70{ }^{0} \mathrm{~F}\left( \pm 15.56{ }^{0} \mathrm{C}-21.11{ }^{\circ} \mathrm{C}\right)$ (Kumulo, 2011).

Berdasarkan penelitian Brigita dan Rahardyan (2013), setiap individu menghasilkan sampah 0.23-2 liter/hari dengan 73\% merupakan sampah organik. Kurangnya upaya dari masyarakat dan pemerintah untuk mengatasi produksi sampah yang tinggi tersebut menjadi suatu permasalahan yang belum dapat diselesaikan, termasuk di Salatiga. Menurut data Badan Pusat Statistik (BPS) yang dipublikasi pada 2016, terjadi kenaikan volume sampah dari tahun 2012 hingga 2015. Pada tahun 2015, volume sampah Kota Salatiga mencapai $427 \mathrm{~m}^{3}$ dan yang berhasil di angkut hanya $322 \mathrm{~m}^{3}$ dengan persentase sampah organik mencapai $70.70 \%$.

Limbah organik lain yang masih belum mampu diolah secara maksimal adalah ampas tahu dan sisa-sisa makanan dari rumah makan. Menurut data Badan Pengkajian dan Penerapan Teknologi (BPPT), dari $80 \mathrm{~kg}$ tahu yang diproduksi akan dihasilkan limbah sebanyak $2,610 \mathrm{~kg}$. Limbah tersebut masih mengandung protein dan lemak sekitar 40\%-60\% (226.06 mg/L sampai 434.78
mg/L), karbohidrat sekitar 25\%-50\%, serta nitrat dan fosfat (Nurhasan, 2010) yang dibutuhkan untuk mikro nutrisi bagi $L$. rubellus.

Penelitian mengenai pengolahan limbah rumah makan serta limbah industri tahu menggunakan $L$. rubellus sudah banyak dipublikasikan namun belum ada penelitian yang memanfaatkan kedua limbah ini secara bersamaan. Pemanfaatan kedua limbah tersebut pada penelitian ini diharapkan dapat berguna untuk meningkatkan kualitas L. rubellus para peternak, meningkatkan kualtias kompos yang dihasilkan, serta membantu menyelesaikan masalah pengolahan dan pemanfatan limbah organik. Penelitian vermikompos yang dilakukan oleh Albasha., dkk. (2015) menggunakan limbah dapur menunjukan bahwa pada hari ke-30 menunjukan peningkatan kadar nitrogen dari $0.14 \%$ menjadi $0,22 \%$, peningkatan kadar fosfat dari $0.76 \%$ menjadi $0,92 \%$, serta peningkatan kadar kalium dari $0.091 \%$ menjadi $0.134 \%$. Penelitian yang dilakukan Prayogi (2014) menunjukan bahwa L. rubellus yang dipelihara pada media $75 \%$ limbah kedelai : $25 \%$ kotoran sapi mempunyai biomassa $2.84 \mathrm{x}$ lebih banyak dibandingkan yang dipelihara pada $100 \%$ kotoran sapi.

Penelitian ini bertujuan untuk mengetahui komposisi media terbaik untuk pertumbuhan $L$. rubellus, ditinjau dari perubahan panjang akhir, laju pertumbuhan relatif berdasarkan panjang, massa kering, dan massa basah akhir. Serta mengetahui komposisi kompos yang dihasilkan dari media yang diperkaya limbah rumah makan dan limbah industri tahu.

\section{METODE PENELITIAN}

\section{Pemilihan Limbah Rumah Makan dan Limbah Tahu}

Limbah rumah makan yang digunakan berasal dari warung nasi sederhana karena merupakan rumah makan yang lazim ditemui di Salatiga. Limbah rumah makan yang digunakan pada penelitian ini berisi nasi, mie, daging ayam, labu, wortel, sawi hijau, sawi putih, daun bawang, brokoli, dan kembang kol. Limbah tahu yang 
digunakan berasal dari industri tahu di daerah Kalitaman, Salatiga.

\section{Persiapan Media dan Perlakuan}

Media pertumbuhan dan percobaan terdiri dari : kotoran sapi, limbah rumah makan, dan limbah tahu. Kotoran sapi diambil dari sapi peliharaan warga Tuntang, Jawa Tengah yang sudah terkena matahari selama sekitar 7 hari. Limbah rumah makan yang dipilah merupakan sisa makanan mudah dihaluskan, misalnya nasi, sayur, atau daging tanpa tulang, kemudian dicuci dengan air mengalir, lalu dihaluskan untuk digunakan sebagai sumber nutrisi dan dicampur kotoran sapi serta limbah tahu dengan kadar air berkisar $75 \%$ (Albasha., dkk, 2015).

Media dengan komposisi 100\% kotoran sapi digunakan sebagai kontrol. Perlakuan A dengan komposisi 50\% kotoran sapi, 25\% limbah rumah makan, 25\% limbah tahu. Perlakuan B dengan komposisi $25 \%$ kotoran sapi, 50\% limbah rumah makan, 25\% limbah tahu, kemudian perlakuan $\mathrm{C}$ dengan komposisi $25 \%$ kotoran sapi, 25\% limbah rumah makan, dan $50 \%$ limbah tahu.

Tabel 1. Kombinasi Perlakuan

\begin{tabular}{lccc}
\hline \multirow{2}{*}{ Perlakuan } & \multicolumn{3}{c}{ Media } \\
\cline { 2 - 4 } & $\begin{array}{c}\text { Kotoran sapi } \\
(\%)\end{array}$ & $\begin{array}{c}\text { Limbah rumah makan } \\
(\%)\end{array}$ & $\begin{array}{c}\text { Limbah tahu } \\
(\%)\end{array}$ \\
\hline Kontrol & 100 & 0 & 0 \\
Perlakuan A & 50 & 25 & 25 \\
Perlakuan B & 25 & 50 & 25 \\
Perlakuan C & 25 & 25 & 50 \\
\hline
\end{tabular}

\section{Persiapan Sebelum Dekomposisi}

Media yang sudah disiapkan kemudian diletakan di wadah berukuran $40 \mathrm{~cm}$ x $40 \mathrm{~cm}$ x 30 $\mathrm{cm}$ dengan massa media $15 \mathrm{~kg} /$ kotak. Kelembaban media dijaga dengan disemprot air menggunakan sprayer apabila sudah mulai kering, diaduk per 2 hari untuk menjaga aerasi. Media juga diberi pengurai organik $\left(\mathrm{EM}_{4}\right)$ sebanyak $10 \mathrm{~mL}$ pada hari pertama. Media disiapkan 7 hari sebelum proses dekomposisi (inkubasi cacing) dilakukan.

\section{Proses Dekomposisi}

Percobaan dekomposisi dilakukan selama 60 hari setelah media siap dengan 100 ekor L. rubellus dari industri kompos Bioflora, Salatiga pada masing-masing percobaan. Cacing yang digunakan sebagai starter dipilih dengan ukuran panjang tubuh rata-rata 2-3 cm (Hursh, 2003). Proses dekomposisi dilakukan di Laboratorium Fakultas Biologi, Universitas Kristen Satya Wacana, Salatiga.
Parameter pengukur dilakukan pada hari ke-0 dan ke-60. Parameter yang diukur untuk pertumbuhan cacing adalah perubahan panjang, laju pertumbuhan relatif panjang, perubahan massa basah, dan perubahan massa kering cacing. Sedangkan untuk komposisi kompos digunakan parameter tingkat $\mathrm{pH}$, persentase $\mathrm{C}, \mathrm{N}, \mathrm{P}$, dan $\mathrm{K}$, serta rasio $\mathrm{C} / \mathrm{N}$. Pengukuran komposisi kompos dilakukan di Pusat Penelitian Karet Balai Penelitian Getas.

\section{Rancangan Penelitian dan Analisis Data}

Penelitian Rancangan Acak Lengkap (RAL) dengan 4 perlakuan $5 x$ ulangan. Data perubahan massa dan panjang diperiksa normalitas dan homogenitas ragam. Kemudian data tersebut dianalisis dengan Multivariate Analysis of Variances (MANOVA) untuk parameter perubahan panjang, massa basah, dan massa kering. Paramater laju pertumbuhan relatif dianalisis dengan One Way Analysis of Variances (ANOVA). Analisis data dilakukan dengan aplikasi SPSS.

\section{Parameter Pengukuran}




\section{HASIL DAN PEMBAHASAN}

\section{Pertumbuhan Cacing Tanah}

Data panjang cacing yang diperoleh dari kontrol, perlakuan A, dan perlakuan B dianalisis secara statistik dengan Uji Bonferoni setelah dilakukan uji beda signifikan dari panjang awal dan panjang akhir serta uji homogenitas variasi data Levene. Tabel berikut merupakan hasil analisis statistik Bonferroni.

Tabel 2. Uji Post Hoc Bonferroni Panjang Akhir Cacing pada Hari ke-60

\begin{tabular}{lcccc}
\hline Variabel Terikat & & (I) Perlakuan & (J) Perlakuan & Perbedaan Rata-Rata (I-J) \\
\hline Panjang Akhir $(\mathrm{cm})$ & Bonferroni & Kontrol & Perlakuan A & $-1.6174^{*}$ \\
& & Perlakuan B & $-0.9950^{*}$ \\
& & Perlakuan A & Kontrol & $1.6174^{*}$ \\
& & Perlakuan B & $0.6224^{*}$ \\
\hline
\end{tabular}

Keterangan: “*” = beda nyata.

Berdasarkan tabel tersebut, dapat dilihat bahwa secara statistik terdapat perbedaan panjang akhir antara kontrol, panjang perlakuan A, dan perlakuan B. Berikut adalah grafik perbandingan hasil rata-rata panjang akhir cacing pada kontrol, perlakuan A, dan perlakuan B. Hasil pertumbuhan cacing tanah yang ditampilkan hanya dari kontrol (100\% kotoran sapi), perlakuan A (50\% kotoran sapi : 25\% limbah rumah makan : 25\% limbah tahu), dan perlakuan B (25\% kotoran sapi : $50 \%$ limbah rumah makan : 25\% limbah tahu).
Perlakuan C (25\% kotoran sapi : 25\% limbah rumah makan : 50\% limbah tahu) tidak dapat diukur karena cacing $100 \%$ mati di waktu kurang dari 14 hari setelah inkubasi. Perlakuan C, dengan komposisi 50\% limbah tahu diperkirakan tidak cocok dengan lingkungan optimum untuk mendukung pertumbuhan cacing tanah karena proses fermentasi dari aktivitas mikroorganisme yang berasal dari $\mathrm{EM}_{4}$. Mikroorganisme pada $\mathrm{EM}_{4}$ akan mendegradasi bahan organik melalui proses fermentasi (Suparman, 1994).

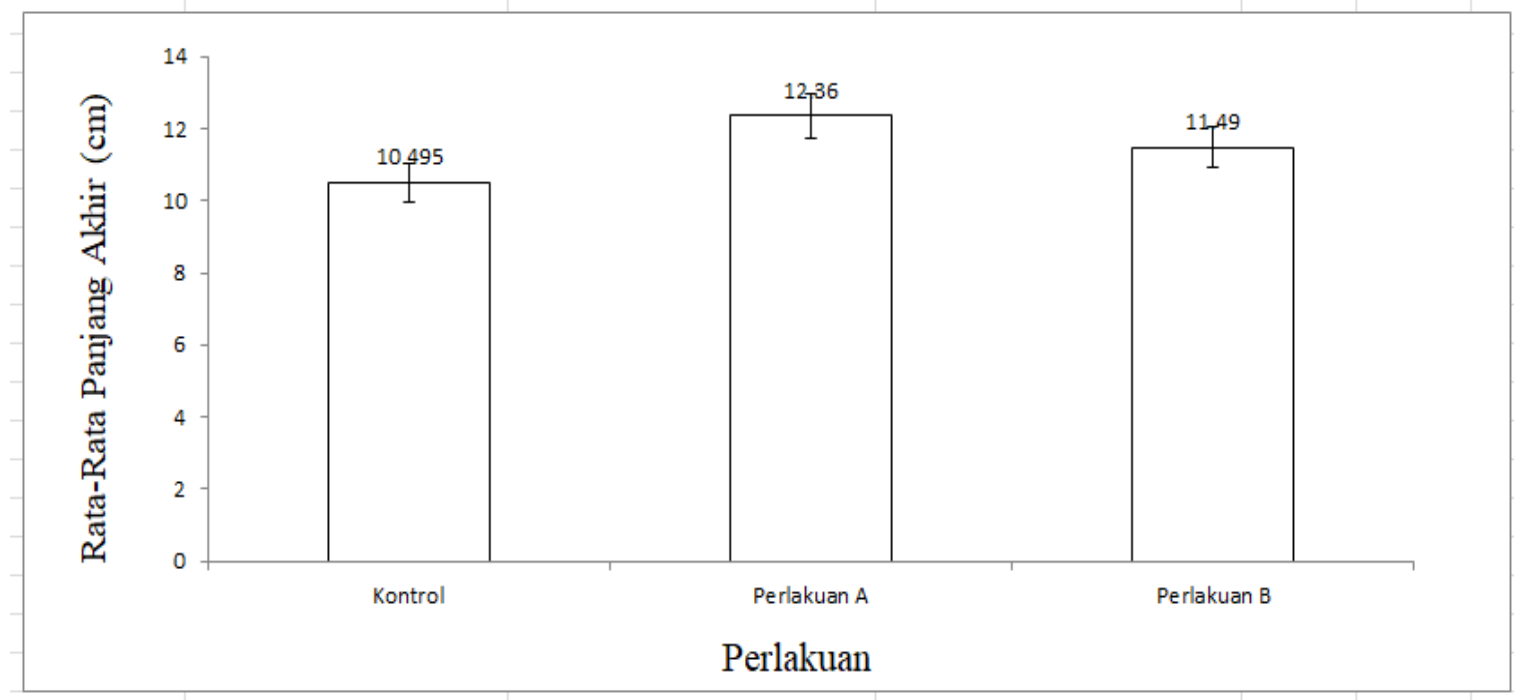

Gambar 1. Grafik Perbandingan Rata-Rata Panjang Cacing (cm) Hari ke-60

Proses fermentasi yang terjadi selama dekomposisi bahan-bahan organik, terutama limbah tahu mengakibatkan penurunan $\mathrm{pH}$ signifikan sehingga tidak cocok untuk pertumbuhan cacing tanah. Berdasarkan penelitian Yousufi (2012), pH terendah bisa mencapai 3 selama proses fermentasi ampas tahu padat dengan mikroorganisme. Berdasarkan penelitian Febrita dkk (2015) $\mathrm{pH}$ sebesar 4.5 sudah tidak mendukung untuk pertumbuhan optimum cacing tanah. Menurut 
Palungkun (2010), pH merupakan salah satu faktor penentu pertumbuhan, apabila $\mathrm{pH}$ lingkungan tumbuh cacing bersifat asam maka akan menghambat pertumbuhan cacing. Media yang terlalu asam ini diperkirakan menjadi faktor utama cacing pada perlakuan $\mathrm{C}$ tidak mampu tumbuh dan mati di usia kurang dari 14 hari setelah inkubasi.
Faktor lain yang diperkirakan menjadi penghambat pertumbuhan cacing tanah pada perlakuan $\mathrm{C}$ adalah kadar amoniak yang tinggi dari ampas tahu (Yulipriyanto, 2010). Amoniak tinggi mengakibatkan degradasi berlangsung cepat (Febrita dkk, 2015) sehingga perubahan suhu media menjadi tidak cocok untuk mendukung pertumbuhan cacing tanah.

Tabel 3. Uji Tukey HSD Variasi Laju Pertumbuhan Relatif Panjang Cacing Tanah

\begin{tabular}{llcccc}
\hline Perlakuan & (J) Perlakuan & Perbedaan & Rata- & Sig. & \multicolumn{2}{c}{ Taraf Kepercayaan 95\% } \\
\cline { 5 - 6 } & Rata (I-J) & & Batas Bawah & Batas Atas \\
\hline \multirow{2}{*}{ Kontrol } & Perlakuan A & $-0.0311^{*}$ & 0.000 & -0.0335 & -0.0286 \\
& Perlakuan B & $-0.0166^{*}$ & 0.000 & -0.0190 & -0.0141 \\
Perlakuan A & Kontrol & $0.0311^{*}$ & 0.000 & 0.0286 & 0.0335 \\
& Perlakuan B & $0.0145^{*}$ & 0.000 & 0.0120 & 0.0170 \\
\hline
\end{tabular}

Keterangan: "**" = beda nyata.

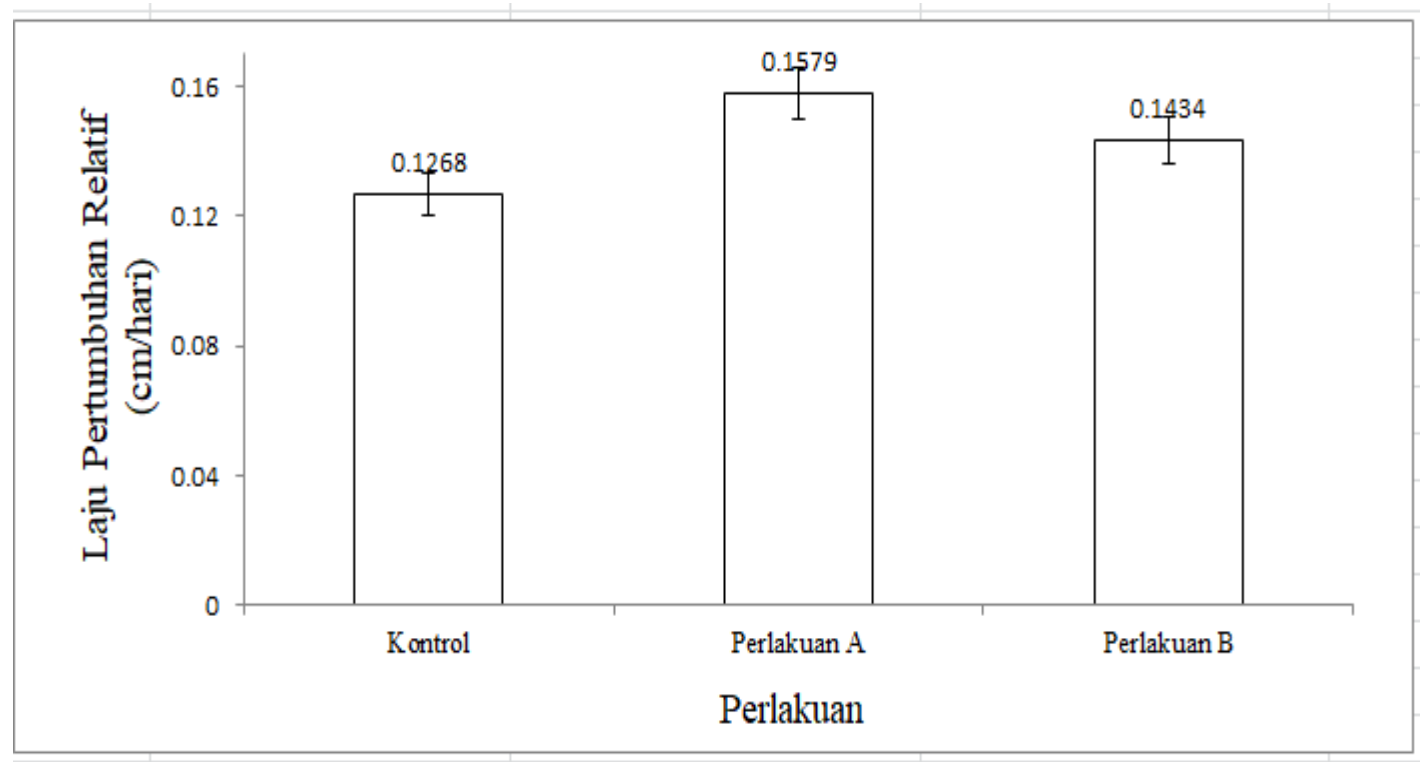

Gambar 2. Grafik Perbandingan Laju Pertumbuhan Relatif (cm/hari) Panjang Cacing Antar Perlakuan

Berdasarkan Uji Tukey HSD yang sudah dilakukan, dapat disimpulkan bahwa terdapat beda nyata untuk LPR antar perlakuan berdasarkan parameter panjang. Rata-rata LPR kontrol sebesar $0.1268 \mathrm{~cm} / \mathrm{hari}$, perlakuan A memiliki nilai 0.1579 $\mathrm{cm} / \mathrm{hari}$, dan perlakuan B sebesar $0.1434 \mathrm{~cm} / \mathrm{hari}$. Berikut adalah grafik perbandingan rata-rata LPR antar perlakuan pada masa inkubasi 60 hari.

Berdasarkan hasil analisis statistik, grafik panjang cacing, dan grafik LPR dapat dilihat bahwa media dengan komposisi $50 \%$ kotoran sapi
(Perlakuan A) menjadi tempat yang paling baik untuk mendukung pertumbuhan panjang cacing tanah. Terbukti dari rata-rata LPR pada perlakuan A pada hari ke-60 memiliki nilai $0.1579 \mathrm{~cm} / \mathrm{hari}$, nilai ini paling tinggi dibandingkan dengan kontrol dengan rata-rata LPR sebesar $0.1268 \mathrm{~cm} /$ hari dan perlakuan B dengan rata-rata LPR sebesar 0.1434 $\mathrm{cm} /$ hari.

Analisis pertumbuhan juga dilihat berdasarkan perubahan massa basah dan massa kering. Data massa yang diperoleh dari kontrol, 
perlakuan A, dan perlakuan B dianalisis secara statistik dengan Uji Bonferoni setelah dilakukan uji beda signifikan dari panjang awal dan panjang akhir serta uji homogenitas variasi data Levene.

Tabel berikut merupakan hasil analisis statistik Bonferroni untuk massa basah pada hari ke-60.

Tabel 4. Uji Post Hoc Bonferroni Massa Basah Cacing pada Hari ke-60

\begin{tabular}{lcccc}
\hline Variabel Terikat & & (I) Perlakuan & (J) Perlakuan & $\begin{array}{l}\text { Perbedaan Rata-Rata (I- } \\
\text { J) }\end{array}$ \\
\hline Massa Basah Akhir & Bonferroni & Kontrol & Perlakuan A & $-0.9891894^{*}$ \\
(gr) & & $\begin{array}{c}\text { Perlakuan B } \\
\text { Kontrol }\end{array}$ & $-0.9053218^{*}$ \\
& & Perlakuan A & $\begin{array}{c}\text { Ko } \\
\text { Perlakuan B }\end{array}$ & $0.083864^{*}$ \\
\hline
\end{tabular}

Keterangan: “*”= beda nyata

Berdasarkan tabel tersebut, dapat dilihat bahwa secara statistik terdapat perbedaan massa basah akhir antara kontrol dengan massa basah perlakuan A dan perlakuan B namun tidak terdapat perbedaan antara perlakuan A dan perlakuan B. Berikut adalah grafik perbandingan hasil rata-rata massa basah akhir dari kontrol, perlakuan A, dan perlakuan B.

Berdasarkan hasil analisis statistik dan grafik massa basah cacing dapat dilihat bahwa perlakuan A menjadi tempat yang lebih baik untuk mendukung pertumbuhan massa cacing tanah dibanding kontrol dan perlakuan B. Hal tersebut dapat dilihat dari rata-rata massa basah cacing tanah setelah hari ke-60 di perlakuan A memiliki beda rata-rata sebesar 0.9982 gr dibanding rata-rata massa bassah pada cacing yang ditumbuhkan pada kontrol dan selisih sebesar 1.0847 gr dibanding perlakuan B. Hasil uji post hoc Bonferroni untuk massa kering cacing pada hari ke-60 dapat dilihat pada tabel 5 .

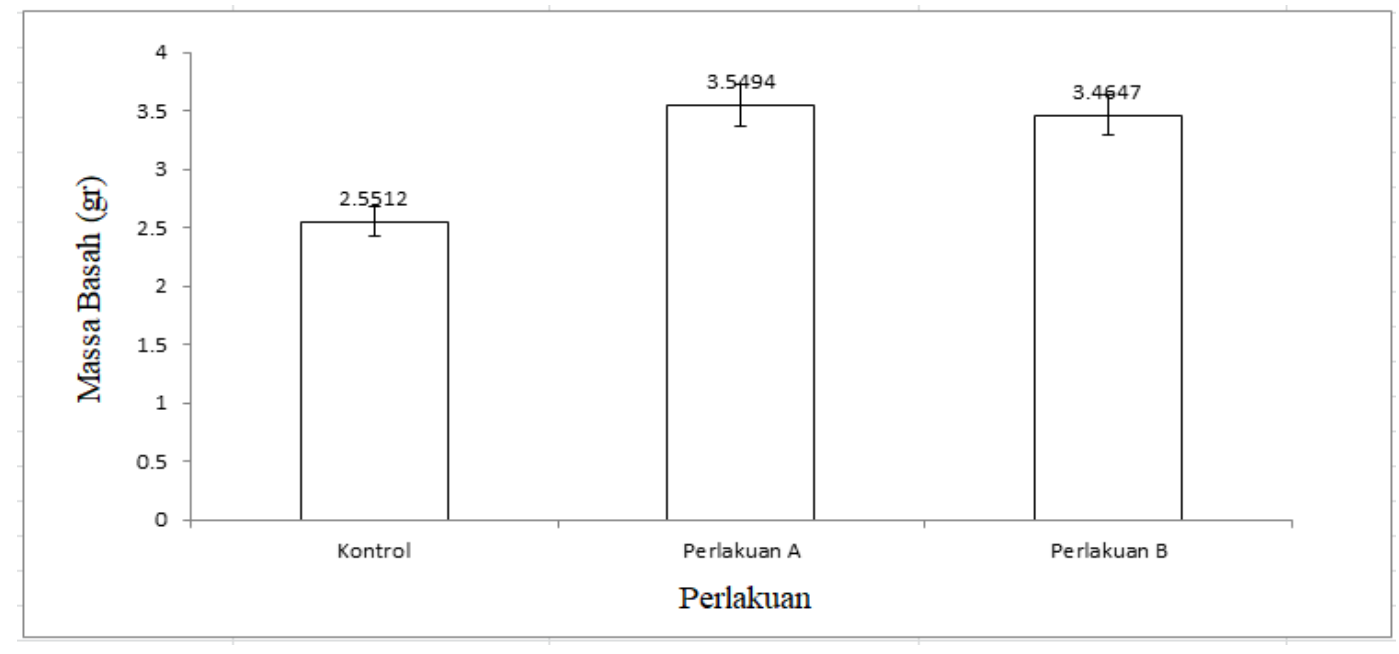

Gambar 3. Grafik Perbandingan Rata-Rata Massa Basah Cacing (gr) pada Hari ke-60

Tabel 5. Uji Post Hoc Bonferroni Massa Kering Cacing pada Hari ke-60

\begin{tabular}{|c|c|c|c|}
\hline Variabel Terikat & (I) Perlakuan & (J) Perlakuan & Perbedaan Rata-Rata (I-J) \\
\hline $\begin{array}{l}\text { Massa Kering Akhir Bonferroni } \\
\text { (gr) }\end{array}$ & $\begin{array}{c}\text { Kontrol } \\
\text { Perlakuan A }\end{array}$ & $\begin{array}{c}\text { Perlakuan A } \\
\text { Perlakuan B } \\
\text { Kontrol } \\
\text { Perlakuan B }\end{array}$ & $\begin{array}{c}-0.0200880^{*} \\
-0.0113290^{*} \\
0.0200880^{*} \\
0.0087590\end{array}$ \\
\hline
\end{tabular}

Keterangan: “*” = beda nyata 
Berdasarkan tabel tersebut, dapat dilihat bahwa secara statistik terdapat perbedaan massa kering akhir antara kontrol dengan massa kering perlakuan A dan perlakuan B namun tidak terdapat perbedaan antara perlakuan A dan perlakuan B. Berikut adalah grafik perbandingan hasil rata-rata massa kering akhir dari kontrol, perlakuan A, dan perlakuan B.

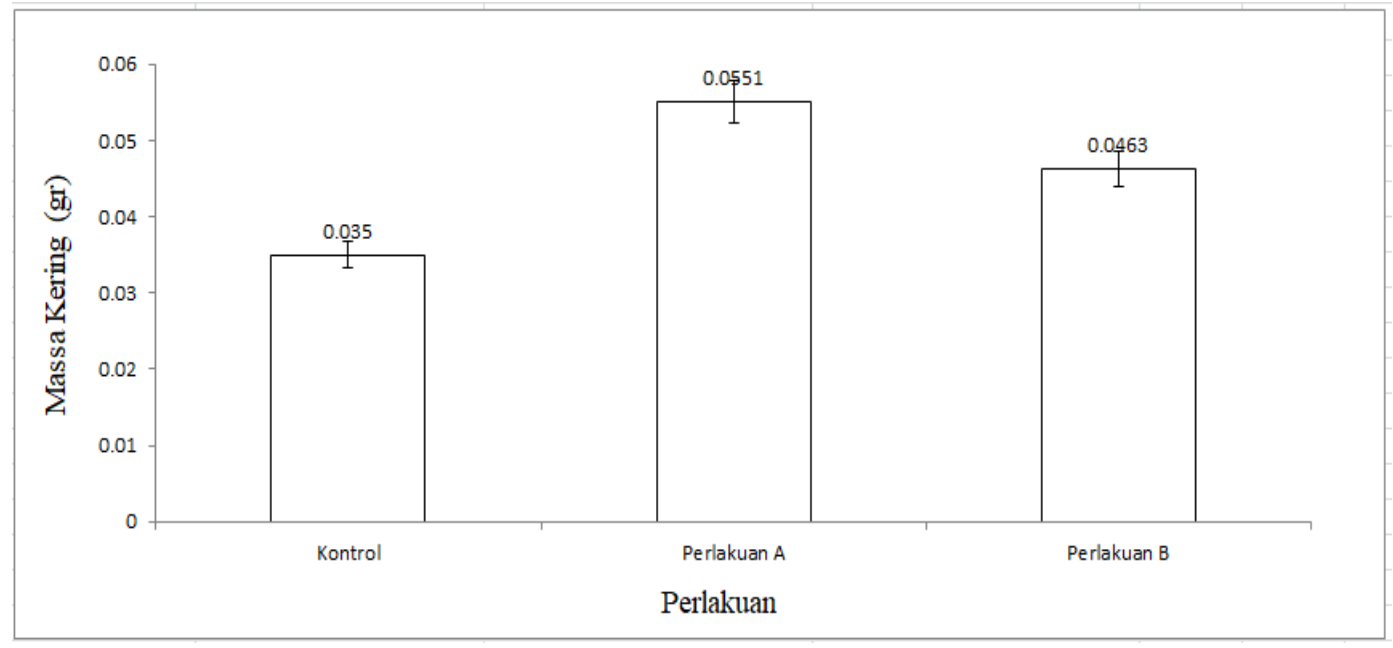

Gambar 4. Grafik Perbandingan Massa Kering Cacing (gr) pada Hari ke-60

Berdasarkan hasil analisis statistik dan grafik massa kering cacing dapat dilihat bahwa perlakuan A menjadi tempat yang paling baik untuk mendukung pertumbuhan massa cacing tanah dibanding kontrol dan perlakuan B. Hal tersebut dapat dilihat dari rata-rata massa kering cacing tanah setelah hari ke-60 di perlakuan A memiliki beda rata-rata sebesar 0.0201 gr dibanding rata-rata massa bassah pada cacing yang ditumbuhkan pada kontrol dan selisih sebesar 0.0088 gr dibanding perlakuan B.

Perlakuan A, dengan komposisi 50\% kotoran sapi menjadi media yang paling baik untuk pertumbuhan cacing tanah dari segi panjang akhir, laju pertumbuhan relatif, dan massa akhir. Hal tersebut dapat dilihat dari hasil penelitian bahwa panjang dan massa cacing yang ditumbuhkan pada perlakuan A memiliki rata-rata panjang, rata-rata LPR, dan massa akhir yang lebih besar dibanding dengan cacing yang ditumbuhkan pada kontrol (100\% kotoran sapi) dan perlakuan B (50\% limbah rumah makan). Hal ini senada dengan penelitian Prayogi (2014) dan Febrita., dkk (2015) bahwa cacing tanah membutuhkan tambahan nutrisi selain yang terdapat pada kotoran sapi.
Pengayaan nutrisi pada penelitian ini berasal dari limbah rumah makan dan industri tahu. Protein merupakan salah satu nutrisi penting untuk mendukung pertumbuhan cacing tanah (Prayitno, 2015), berdasarkan hal tersebut protein dari kombinasi sisa makanan yang terdapat daging dan ampas tahu mampu mendukung pertumbuhan cacing tanah. Kadar protein per 100g ampas tahu padat mencapai 17.4 gr (Suprapti, 2005). Selain protein, selulosa yang terdapat pada sisa makanan berupa sayur, seperti sawi, daun bawang, dan brokoli juga membantu pertumbuhan cacing tanah. Monebi dan Ugwumba (2013), menyatakan bahwa cacing tanah yang dipelihara pada media dengan selulosa menunjukkan angka pertumbuhan yang lebih baik dibandingkan pada cacing yang dipelihara pada tanah saja. Hal tersebut diperkirakan karena terdapat aktivitas mikroorganisme yang semakin baik apabila pada medium terdapat selulosa, mikroorganisme tersebut membantu perombakan selulosa sehingga memudahkan cacing tanah dapat menggunakannya sebagai salah satu sumber karbon.

Meskipun demikian, komponen utama yaitu kotoran sapi tetap harus diberikan lebih banyak karena bahan lain hanya bersifat pendukung. Hal 
tersebut dapat dilihat dari perbedaan rata-rata panjang akhir dan LPR antara perlakuan A dibandingkan dengan perlakuan B. Berdasarkan uji statistik, terdapat beda nyata antara rata-rata panjang akhir dan LPR diantara kedua perlakuan tersebut, artinya cacing tanah masih membutuhkan nutrisi dari kotoran sapi untuk mendukung pertumbuhan dibanding nutrisi dari limbah rumah makan karena pada perlakuan B persentase kotoran sapi lebih rendah $25 \%$ dibanding perlakuan A.

\section{Kualitas Kompos}

Kompos yang dihasilkan berdasarkan kadar $\mathrm{N}, \mathrm{P}, \mathrm{K}$, dan $\mathrm{C}$ organik sudah melebihi standar yang diatur Permentan No. 70 tahun 2011 tentang Pupuk Organik, Pupuk Hayati dan Pembenah Tanah dan Standar Nasional Indonesia (SNI) 19-7030-2004 tentang Spesifikasi Kompos dari Sampah Organik
Domestik. Kadar pH sudah sesuai dengan Permentan No. 70 tahun 2011, namun masih lebih besar dibanding standar SNI 19-7030-2004. Nilai rasio $\mathrm{C} / \mathrm{N}$ kompos yang dihasilkan juga masih dibawah standar Permentan dan SNI. Berikut adalah tabel perbandingan komposisi kompos hasil penelitian dengan standar Permentan No. 70 tahun 2011 dan SNI 19-7030-2004.

Nilai rasio $\mathrm{C} / \mathrm{N}$ dapat digunakan sebagai indikator kematangan kompos, semakin kecil nilai rasio $\mathrm{C} / \mathrm{N}$ maka menandakan bahwa kompos sudah mancapai tahap akhir. Semakin besar nilai rasio $\mathrm{C} / \mathrm{N}$ maka semakin sulit kompos untuk diuraikan dan dimanfaatkan oleh tumbuhan, namun nilai rasio $\mathrm{C} / \mathrm{N}$ yang terlalu rendah akan mengakibatkan kandungan nitrogen banyak terbuang sia-sia ke lingkungan (Kusuma., dkk, 2017).

Tabel 6. Tabel Perbandingan Kualitas Kompos Penelitian

\begin{tabular}{lccccc}
\hline & Kontrol & Perlakuan & Perlakuan & Permentan No. & SNI \\
A & \multicolumn{2}{c}{$\begin{array}{l}\text { B } \\
\text { 70 tahun 2011 }\end{array}$} & $19-7030-2004$ \\
\hline$\% \mathrm{C}$ & 17.03 & 20.99 & 18.06 & 15 & $9.8-32$ \\
$\% \mathrm{~N}$ & 2.13 & 2.42 & 2.61 & & 0.4 \\
$\% \mathrm{P}$ & 0.67 & 0.73 & 0.78 & $4^{*}$ & 0.1 \\
$\% \mathrm{~K}$ & 3.14 & 2.49 & 2.22 & & 0.2 \\
Rasio & 8.00 & 8.67 & 6.92 & $15-25$ & $10-20$ \\
$\mathrm{C} / \mathrm{N}$ & 8.61 & 8.64 & 8.14 & $4-9$ & $6.8-7.49$ \\
$\mathrm{pH}$ & \multicolumn{2}{l}{ Keterangan: “*” = total keseluruhan kadar N. P, dan K }
\end{tabular}

Hasil komposisi kompos berdasarkan rasio $\mathrm{C} / \mathrm{N}$ mirip dengan penelitian yang dilakukan Albasha., dkk (2015). Penelitian tersebut juga menghasilkan rasio $\mathrm{C} / \mathrm{N}$ yang rendah pada hari ke60 dari pengolahan sampah dapur. Rasio C/N yang didapatkan pada penelitian tersebut di hari ke-60 sebesar 5.45.

Meskipun rasio $\mathrm{C} / \mathrm{N}$ kompos dari penelitian ini belum mencukupi standar dari Permentan No. 70 tahun 2011 dan SNI 19-7030-2004, namun rasio $\mathrm{C} / \mathrm{N}$ kompos ini sudah dapat digunakan sebagai pupuk. Menurut Indumathi (2017), rasio C/N dibawah 20 menunjukkan bahwa proses dekomposisi sudah memasuki tahap akhir dan kompos sudah dapat digunakan sebagai pupuk. Namun rasio $\mathrm{C} / \mathrm{N}$ yang lebih disukai benilai 15 atau kurang.
Rasio $\mathrm{C} / \mathrm{N}$ yang rendah dapat ditingkatkan agar bisa sesuai dengan standar Permentan No. 70 tahun 2011 dan SNI 19-7030-2004. Menurut Brady dan Well (2018), nilai rasio C/N yang rendah dapat diatasi dengan menambahkan substrat dengan kandungan unsur karbon tinggi sampai didapatkan nilai rasio $\mathrm{C} / \mathrm{N}$ yang diinginkan.

Apabila ditinjau dari kadar N, P, dan K yang dihasilkan, kompos ini sudah jauh melebihi standar Permentan No. 70 tahun 2011 dan SNI 19-70302004, artinya sudah layak untuk digunakan pada tumbuhan. Penelitian Albasha., dkk (2015) juga menunjukkan hasil serupa, yaitu kadar N, P, dan K mengalami peningkatan pada hari ke-60. Kondisi tersebut adalah hal yang wajar terjadi karena proses perombakan dari bahan organik (limbah rumah makan dan ampas tahu) oleh cacing tanah dan 
mikroorganisme $\left(\mathrm{EM}_{4}\right)$. Materi organik pada akhirnya akan terurai menjadi materi-materi anorganik seperti $\mathrm{N}, \mathrm{P}$, dan $\mathrm{K}$.

Tingkat keasaman $(\mathrm{pH})$ dari kompos yang dihasilkan tergolong bersifat alkali (basa) dengan tingkat $\mathrm{pH}$ berkisar 8 . Tingkat keasaman sudah sesuai dengan standar Permentan No. 70 tahun 2011 namun belum sesuai dengan SNI 19-70302004. Tingkat keasaman yang tergolong alkali tersebut dapat diakibatkan dari hasil demineralisasi unsur mikro misalnya kalsium dan kalium (Dewi., dkk, 2017) pada sayur dari sisa limbah rumah makan yang digunakan, seperti brokoli dan sayuran lain. Menurut Fabbri dan Crosby (2016), brokoli yang dimasak memiliki kandungan kalsium $\left(\mathrm{Ca}^{2+}\right)$ berkisar $40 \mathrm{mg} / 100 \mathrm{gr}$ dan kandungan kalium $\left(\mathrm{K}^{+}\right)$ berkisar $293 \mathrm{mg} / 100 \mathrm{gr}$. Demineralisasi tidak hanya berasal dari kalsium dan kalium saja, namun juga unsur mikro lain seperti magnesium $\left(\mathrm{Mg}^{2+}\right)$ sehingga unsur-unsur tersebut akan berikatan dengan asam yang muncul selama proses dekomposisi dan mengakibatkan $\mathrm{pH}$ akhir kompos yang tergolong alkali.

Sifat alkali dari kompos yang dihasilkan dapat ditambahkan senyawa yang bersifat asam, misalnya sulfur dalam bentuk sulfat $\left(\mathrm{SO}_{4}\right)$ agar tingkat $\mathrm{pH}$ dapat sesuai dengan ketentuan SNI 197030-2004. Penambahan sulfat berdasarkan penelitian yang dilakukan Singh dkk (2018) juga dapat meningkatkan hasil pertanian. Penelitian tersebut menunjukkan rata-rata peningkatan hasil panen pada gandum musim semi hingga 36\% dibandingkan kontrol.

\section{KESIMPULAN}

Komposisi 50\% kotoran sapi : 25\% limbah rumah makan : 25\% limbah tahu (perlakuan A) merupakan media paling baik untuk mendukung pertumbuhan cacing tanah ditinjau dari hasil ratarata panjang akhir, rata-rata LPR, massa basah akhir, dan massa kering akhir dari cacing tanah yang ditumbuhkan di media tersebut lebih besar dibanding dengan media lain. Komposisi kompos yang dihasilkan sudah sesuai dengan standar dari Permentan No. 70 tahun 2011, baik dari kandungan $\mathrm{C}, \mathrm{N}, \mathrm{P}, \mathrm{K}$, dan $\mathrm{pH}$. Rasio $\mathrm{C} / \mathrm{N}$ dari kompos yang dihasilkan juga sudah cukup untuk menjaga kesuburan tanah, namun masih perlu perlakuan tambahan yaitu penambahan unsur $\mathrm{C}$ agar didapatkan nilai rasio $\mathrm{C} / \mathrm{N}$ kompos lebih maksimal.

\section{DAFTAR PUSTAKA}

Albasha, M. O., P. Gupta., dan P. W. Ramteke. 2015. Management of Kitchen Waste by Vermicomposting Using Earthworm, Eudrilus eugeniae. Prosiding International Conference on Advances in Agricultural, Biological \& Environmental Sciences (AABES-2015). London: 22-23 Juli 2015.

Bang, H. T. T., N. T. T. Hang., N. N. Vu., T. H. Phuoc. 2016. Influence of Different Cultivating and Food Sources on Growth of Earthworm, Perionyx excavates (Perr.). Journal of Science Ho Chi Minh City Open University Vol. 1 (17) $2016:$ 60-64.

Brady, N. C. dan R. R. Well. 2018. Elements of the Nature and Properties of Soils. Canada., Pearson Education.

Brigita, G dan B. Rahardyan. 2013. Food Waste Management Analysis in Bandung City. Jurnal Teknik Lingkungan Vol. 19 (1) 2013 : 34-45.

Dewi, N. M. E. Y., Y. Setiyo., I. M. Nada. 2017. Pengaruh Bahan Tambahan pada Kualitas Kompos Kotoran Sapi. Jurnal Beta (Biosistem dan Teknik Pertanian) Vol. 5 2017:76-82.

Fabbri, A. D. T. dan G. A. Crosby. 2016. A Review of the Impact of Preparation and Cooking on the Nutritional Quality of Vegetables and Legumes. International Journal of Gastronomy and Food Science Vol. 32016 : 2-11.

Febrita, E., Darmadi., dan E. Siswanto. 2015. Pertumbuhan Cacing Tanah (Lumbricus rubellus) dengan Pemberian Pakan Buatan untuk Mendukung Proses Pembelajaran pada Konsep Pertumbuhan dan Perkembangan Invertebrata. Jurnal Biogenesis Vol. 11 (2) 2015: 169-176.

Hermawan, R. 2014. Usaha Budidaya Cacing Lumbricus Multiguna dan Prospek Ekspor Tinggi. Jogjakarta., Pustaka Baru Press. 
Hursh, C. 2003. Basic Composting : All the Skills and Tools You Need to Get Started. Lanham., Stackpole Books.

Indumathi, I. 2017. Microbial Conversion of Vegetable Wastes for Bio Fertilizer Production. IOSR Journal of Biotechnology and Biochemistry Vol. 3 (2) 2017 : 43-47.

Kumolo, D.C. 2011. Kaya Raya dari Budidaya Cacing Tanah dan Cacing Sutra. Jogjakarta., Arta Pustaka.

Kusuma, A. P. M., Dery, B., dan Margono. 2017. Pengaruh Penambahan EM-4 dan molasses terhadap Proses Composting Campuran Daun Angsana (Pterocarpus indicun) dan Akasia (Acasia auriculiformis). Jurnal Rekayasa Proses Vol. 1 2017:19-23.

Nurhasan, P. B. 2010. Pengolahan Air Limbah Industri Tahu. Semarang., Yayasan Bina Lestari dan WALHI.

Palungkun, R. 1999. Sukses Beternak Cacing Tanah. Jakarta., Penebar Swadaya.

Prayitno. 2015. Pertumbuhan Cacing Tanah Eisenia fetid asp. pada Kompos Limbah Fleshing. Majalah Kulit, Karet, dan Plastik Vol. 31 2015:85-92.

Prayogi, H.S. 2014. The Effect of Feeding Takara (Soy Pulp) and Dairy Cow Feces for Lumbricus rubellus. International Journal of Current Research and Review Vol. 6 (8) 2014: 1-3.

Rukmana, R. 1999. Budi Daya Cacing Tanah. Jogjakarta., Kanisius.

Singh, S., D. Sarkar., Mehjabeen., M. Bhudevi., S/ Rakesh., R. K. Singh., S. Kar., dan A. Rakshit. 2018. Advanced Forms of Sulphur Formulations for Improving Use Efficiency in Crop Species. Jurnal Annual Research \& Review in Biology Vol. 27 (1) $2018: 1-14$.

Suparman, M. 1994. EM4 Mikroorganisma yang Efektif. Sukabumi., KTNA.

Suprapti, M. L. 2005. Pembuatan Tahu. Jogjakarta., Kanisius.
Monebi, C.O. dan A.A.A. Ugwumba. 2015. Utilization of the Earthworm, Eudrilus eugeniae in the Diet of Heteroclarias fingerlings. International Journal of Fisheries and Aquaculture Vol. 5 (2) 2013:19-25.

Yousufi, M. K. 2012. Impact of $p H$ on the Single Cell Protein Produced on Okara-Wheat Grit Substrates Using Rhizopus oligosporus and Aspergillus oryzae. Journal of Environmental Science, Toxicology and Food Technology. Vol. 1 Issue 2: 32-35.

Yulipriyanto, H. 2010. Biologi Tanah dan Strategi Pengelolaannya. Jogjakarta., Graha Ilmu. 